Volume 1, Nomor 2 Oktober 2019

ISSN : 2656-9639 (Cetak)

ISSN : 2684-9046 (Online)

\title{
ANALISIS SAH TIDAKNYA SUATU PERJANJIAN INTERNASIONAL MENURUT HUKUM INTERNASIONAL (Studi Kasus Perjanjian Helsinki Antara GAM dengan Indonesia)
}

\author{
Devi Yusvitasari \\ Mahasiswa S1 Program Studi Ilmu Hukum \\ Jurusan Hukum dan Kewargenegaraan \\ Fakultas Hukum dan Ilmu Sosial \\ Universitas Pendidikan Ganesha
}

\begin{abstract}
Abstrak
Konflik bersenjata yang terjadi di Aceh mulai mereda sejak adanya MoU antara Pemerintah Republik Indonesia dan Gerakan Aceh Merdeka (GAM) pada 15 Agustus 2005 di Helsinki, Finlandia. MoU Helsinki mampu menghentikan konflik bersenjata di Aceh karena pelarangan dalam penggunaan senjata secara eksplisit diatur pada beberapa pasal MoU Helsinki. MoU Helsinki merupakan Nota Kesepahaman antara Pemerintah Republik Indonesia (RI) dengan Gerakan Aceh Merdeka (GAM) tentang penyelesaian konflik Aceh secara damai berdasarkan hasil perundingan di Helsinki, Finlandia. Rumusan masalah yang diangkat terkait status hukum nota MoU Helsinki ditinjau berdasarkan hukum hukum perjanjian internasional serta apakah MoU tersebut tunduk terhadap hukum internasional atau tidak Penelitian ini menggunakan metode yuridis normatif dengan menekankan pada penggunaan sumber data sekunder sebagai acuan utama. Metode pendekatan menggunakan pendekatan perundang-undangan, conceptual approach, case approach, statute approach dan historis. Hasil penelitian didapatkan bahwa latar belakang adanya MoU Helsinki karena adanya ketidakadilan terhadap masyarakat Aceh. MoU Helsinki bukan merupakan perjanjian internasional karena GAM termasuk kepada kaum belligerent /bukan sebagai subyek hukum internasional sehingga tidak dapat dikatakan sebagai pernjanjian yang tunduk pada hukum internasional karena tidak dapat dibuktikan sejak perundingan, pembuatan naskah perjanjian, pemberlakuan, pelaksanaan, hingga penyelesaian sengketa. Saran dari penulisan ini adalah mengutamakan upaya damai sebagai cara penyelesaian konflik, pengawalan pelaksanaan isi MoU Helsinki dan penegakkan kasus pelanggaran HAM.
\end{abstract}

Kata Kunci: MoU Helsinki, GAM, perjanjian internasional

\begin{abstract}
The armed conflict that occurred in Aceh began to subside since the MoU between the Government of the Republic of Indonesia and the Free Aceh Movement (GAM) on August 15, 2005 in Helsinki, Finland. The Helsinki MoU was able to stop armed conflict in Aceh because the ban on the use of weapons was explicitly regulated in several articles of the Helsinki MoU. The Helsinki MoU is a Memorandum of Understanding between the Government of the Republic of Indonesia (RI) and the Free Aceh Movement (GAM) regarding the peaceful resolution of the Aceh conflict based on the results of negotiations in Helsinki, Finland. The formulation of the issues raised regarding the legal status of the Helsinki MoU memorandum is reviewed based on the law of international treaty law and whether or not the MoU is subject to international law. The method of approach uses a
\end{abstract}


Volume 1, Nomor 2 Oktober 2019

ISSN : 2656-9639 (Cetak)

ISSN : 2684-9046 (Online)

statutory approach, conceptual approach, case approach, statute approach and historical. The results showed that the background to the Helsinki MoU was due to injustice against the people of Aceh. The Helsinki MoU is not an international treaty because GAM is included in the belligerents / not as subjects of international law so that it cannot be said to be an agreement subject to international law because it cannot be proven from the negotiation, drafting the treaty, enactment, implementation, until dispute resolution. Suggestions from this paper are to prioritize peaceful efforts as a way to resolve conflicts, oversee the implementation of the Helsinki MoU and uphold cases of human rights violations.

Keywords: Helsinki MoU, GAM, international agreements

\section{Pendahuluan}

Aceh merupakan salah satu provinsi yang diberikan otonomi khusus oleh pemerintrah pusat Republik Indonesia, pemberian hak atas otonomi khusus kepada provinsi Aceh tersebut tidak terlepas dari konflik internal diwilayah Aceh yang di aktori atau dimainkan oleh GAM (Gerakan Aceh Merdeka). Di deklarasikannya Gerakan Aceh Merdeka (GAM) pertama kali pada tanggal 4 desember 1976, lahirnya GAM itu sendiri diawali karena keinginan untuk melepaskan diri/ wilayah Aceh dari pemerintah pusat negara republic Indonesia (NKRI), hal tersebut dilakukan disebabkan oleh sikap deskriminasi yang dilakukan oleh pemerintah pada masa orde baru atas perekonomian (hasil kekayaan alam Aceh) dan bidang politik Aceh. Oleh karena itu, pihak GAM merasa bahwa hasil kekayaan alam Aceh telah dirampas atau telah dikuasai oleh pemerintah pusat, maka dengan niat ingin memperjuangkan haknya ia meminta untuk melepaskan diri dari NKRI

(http://officialwaru.wordpress.com).

Konflik berkepanjangan di Aceh yang dilakukan oleh GAM dengan TNI- RI atau pemerintah pusat yang telah terjadi bertahun- tahun dan telah menewaskan banyak masyarakat sipil Aceh itu berkahir secara damai setelah musibah dahsyat (gempa dan tsunami pada 26 desember 2004) terjadi di bumi serambi mekkah tersebut, tepatnya pada tanggal 15 Agustus 2005 pihak GAM dan pemerintah RI bersepakat untuk menandatangani akta kesepahaman (MoU) perdamaian di Helsinky, Finlandia. Penandatanganan nota $\mathrm{MoU}$ perdamaian tersebut dari pihak GAM diwakili oleh Malik Mahmud selaku pimpinan GAM sedangkan dipihak pemerintahan RI diwakili oleh Hamid Awaluddin selaku Menteri Hukum dan HAM RI. Pertemuan kesepakatan perdamaian antara GAM dan pemerintah RI tersebut di bantu atau disponsori oleh pihak ketiga yaitu mantan presiden Finlandia Martti Ahtissaari yang juga mejabat sebagai presiden Crisis Management Initiative (CMI). Penandatangaan nota perdamaian tersebut juga disaksikan oleh seluruh rakyat Indonesia, khusunya rakyat Aceh melalui saluran televisi.

Dalam konsideran nota kesepahaman perdamaian tersebut menegaskan bahwa dengan ditanda tanganinya nota perdamaian tersebut maka seluruh konflik persenjatan yang terajadi di bumi Aceh antara GAM dengan TNI- RI telah berakhir secara damai, menyeluruh, berkelanjutan, dan bermartabat bagi semua. Dari MoU tersebut juga lahir 
Volume 1, Nomor 2 Oktober 2019

ISSN : 2656-9639 (Cetak)

ISSN : 2684-9046 (Online)

beberapa kesepakatan yang telah disetujui antara pihak GAM dan pemerintah RI, diantaranya adalah sebagai berikut:

1. Penyelenggaraan pemerintahan Aceh, yang meliputi Undangundang tentang penyelenggaraan pemerintahan di Aceh, partisipasi politik, ekonomi, dan peraturan perundang-undangan

2. Hak asasi manusia

3. Amnesti dan Reintegrasi ke dalam masyarakat

4. Pengaturan keamanan

5. Pembentukan visi monitoring Aceh

6. Penyelesaian perselisihan.

Nota perdamaian antara GAM dan pemerintah republik Indonesia menggunakan nama MoU (Momerendum of Understanding) yang merupakan istilah lain dalam istilah perjanjian internasional atau dikenal juga sebagai MoU Helsinky karena pelaksaanannya dilakukan di Negara Helsinky, Finlandia. Mengenai hal tersebut timbul suatu pertanyaan besar, apakah karena perjanjian tersebut menggunakan istilah MoU dan dilaksanakan penandatangannya di Helsinky dapat dikatakan sebagai sebuah perjanjian internasional?. Melihat pengertian dari hukum perjanjian internsional itu sendiri sebagaimana yang telah di jelaskan dalam aturan hukum internasional (konvensi wina 1969), dalam aturan hukum nasional Indonesia (UU nomor 20 tahun 2000 tentang perjanjian internasional), serta dalam beberapa referensi menyebutkan bahwa semua perjanjian internasional merupakan sebuah perjanjian yang dilakukan oleh dua negara atau lebih dan/atau yang dilakukan oleh subyek hukum internasional sesuai dengan aturan hukum internasional yang dapat menimbulkan hak dan kewajiban serta akibat hukum bagi para pihak. Dari definisi tersebut telah jelas menyebutkan kriteria dari hukum perjanjian internasional. Sedangkan $\mathrm{MoU}$ perdamaian antara GAM dengan Indonesia hanya dilakukan oleh sebuah organisasi nasional (GAM) dengan Indonesia yang keduanya masih dalam ruang lingkup nasional. Dimana status GAM sebagai organisasi juga belum diakui oleh dunia internasional.

\section{Rumusan Masalah}

Berdasarkan latar belakang yang telah penulis uraikan di atas, dalam rumusan masalah ini penulis merumuskan:

1. Bagaimana status hukum nota $\mathrm{MoU}$ perdamaian antara GAM dengan pemerintah RI ditinjau berdasarkan hukum hukum perjanjian internasional?

2. Apakah MoU tersebut tunduk terhadap hukum internasional atau tidak?

\section{Tujuan Penulisan}

Adapun yang menjadi tujuan dalam penulisan ini adalah untuk mengetahui:

1. Untuk mengetahui status hukum nota MoU perdamaian antara GAM dengan pemerintah RI ditinjau berdasarkan hukum hukum perjanjian internasional

2. Untuk mengetahui apakah MoU tersebut tunduk terhadap hukum internasional atau tidak

\section{Manfaat}

Adapun manfaat dari penelitian ini adalah sebagai berikut:

1. Diharapkan, penelitian ini dapat memberikan kontribusi secara teoritis bagi penggiat hukum internasional yang khususnya membahas mengenai sah atau 
Volume 1, Nomor 2 Oktober 2019

ISSN : 2656-9639 (Cetak)

ISSN : 2684-9046 (Online)

tidaknya suatu perjanjian yang dibuat menurut hukum internasional.

2. Hasil dari penelitian ini diharapkan pula dapat memberikan informasi kepada masyarakat umum dan juga pemerintah dalam menanggapi kasus yang serupa jika terjadi di masa yang akan datang.

\section{Metode Penelitian}

Metode penelitian yang digunakan adalah yuridis normatif, yaitu metode yang menitikberatkan pada penelitian data kepustakaan atau disebut data sekunder serta mengkaji ketentuan Konvensi Wina 1969 mengenai perjanjian internasional dan regulasi internasional lainnya dalam kaitannya dengan perjanjian perdamaian atau Memorandum of Understanding (MoU) antara Pemerintah Republik Indonesia dengan Gerakan Aceh Merdeka pada 15 Agustus 2005 silam mengenai status hukum GAM dalam membuat perjanjian tersebut serta apakah MoU tersebut tunduk terhadap hukum internasional atau tidak. Penelitian ini dilakukan dengan cara mengumpulkan dan mempelajari bahan hukum primer, sekunder, dan tertier. Bahan hukum primer seperti Konvensi Wina 1969, MoU Helsinki, Protokol Tambahan I dan II tahun 1977 dan lain-lain. Bahan hukum sekunder seperti buku-buku, artikel, pendapat pakar hukum internasional maupun jurnal dan makalah yang berhubungan dengan topik penulisan ini. Bahan hukum tertier adalah bahan hukum penunjang yang memberikan petunjuk terhadap bahan hukum primer dan sekunder seperti kamus hukum, kamus bahasa, dan lainlain. Untuk menganalisis data dan menarik kesimpulan dari penelitian ini, penulis melakukan analisis dengan metode kualitatif untuk selanjutnya disajikan dalam bentuk preskriptis analisis yang bertujuan untuk memberikan gambaran atau merumuskan suatu permasalahan sesuai dengan keadaan atau fakta yang ada. Penelitian preskriptif juga merupakan penelitian hukum dalam rangka untuk menemukan aturan hukum, prinsipprinsip hukum, norma maupun doktrindoktrin hukum guna menjawab isu hukum yang dihadapi. Selain itu, penelitian hukum preskriptis harus menggunakan beberapa metode pendekatan, seperti: pendekatan konseptual (conceptual approach) yang akan mengkaji persoalan dalam perspektif teori, pendekatan kasus (case approach) pendekatan historis yaitu dengan membahas latar belakang lahirnya dan perkembangan pengaturan mengenai masalah yang diteliti, sekaligus dikaitkan dengan pendekatan (statute approach) undang-undang yakni dengan peraturan-peraturan hukum yang ada. Obyek penelitian pada penelitian ini adalah MoU Helsinki dan MoU Helsinki itu sendiri dari persepktif hukum internasional.

\section{Pembahasan \\ Pengertian Perjanjian Internasional}

Dewasa ini perjanjian internasional dianggap sangap penting dan sangat berperan dalam sebagai sarana untuk meningkatkan kerja sama berskala internasional, perjanjian internasional juga dapat menjadi instrumen utama pelaksanaan hubungan internasional antar negara. Secara teoritis, T. May Rudy (2002) dalam bukunya Hukum Internasional 2 mendefiniskan perjanjian internasional sebagai sebuah perjanjian yang diadakan antara anggota 
Volume 1, Nomor 2 Oktober 2019

ISSN : 2656-9639 (Cetak)

ISSN : 2684-9046 (Online)

masyarakat bangsa- bangsa dan bertujuan untuk menimbulkan akibat hukum tertentu. Sedangkan secara yuridis, pengertian perjanjian internasional dapat ditemukan dalam bberapa aturan hukum yang mengatur mengenai hal tersebut, diantaranya yaitu konvensi wina 1969, konvensi wina 1986, undang- undang nomor 37 tahun 1999 tentang hubungan luar negeri, dan undang- undang nomor 24 tahun 2000 tentang perjanjian internasional. Dalam pasal 2 ayat 1 huruf a konvesi wina tahun 1969 perjanjian internasional diartikan sebagai suatu perjanjian yang dibuat antara serikat-serikat dalam bentuk tertulis dan diatur oleh hukum internasional, baik yang terdapat dalam instrument tunggal atau dalam dua atau lebih instrument terkait dan apapun sebutan yang khusus. Konvensi wina 1969 ini hanya dapat digunakan terhadap sengketa mengenai perjanjian yang dibentuk negara dengan negara dan bentuknya harus tertulis. Untuk sengketa yang pihaknya bukan negara misalnya organisasi internasional pengaturannya diatur dalam konvensi wina 1986 tentang perjanjian internasional untuk sesama organisasi internasional atau organisasi dengan negera (Sefriani;2010). Perjanjian internasional memiliki beberapa istilah atau nama diantaranya adalah sebagai berikut; convention, final act arrangement, declaration, memorandum of undern standing (MOU), agreement, protocol, dan lainlain (Harry Purwanto). Istilah- istilah ini hanya merupakan penyebutan atau nama lain dari perjanjian internasional, dan tidak membawa dampak yuridis terhadap perjanjian internasional yang dilakukan oleh para subyek hukum internasional.

\section{Subyek Hukum Internasional}

Subyek hukum adalah pihak yang dapat dibebani hak dan kewajiban yang diatur dalam hukum. Sedangkan subyek hukum internasional merupakan pihak yang dapat dibebani hak dan kewajiban yang diatur oleh hukum internasional, hak kewajiban yang diatur hukum internasional mencakup hak dan kewajiban yang diatur oleh hukum ingternasional material dan hukum internasional formil. Subyek hukum internasional adalah person dalam hukum internasional (Sugeng;2010). Subyek- subyek hukum international tersebut seharusnya memiliki kecakapan-kecakapan hukum international utama untuk mewujudkan kepribadian hukum internasionalnya. Kecakapan hukum yang dimaksud adalah sebagai berikut (Sefriani):

1. Mampu untuk menuntut hakhaknya didepan pengadilan internasional maupun nasional

2. Menjadi subyek dari beberapa atau semua kewajiban yang diberikan oleh hukum internasional

3. Mempu membuat perjanjian internasional yang sah dan mengikat dalam hukum internasional

4. Menikmati imunitas dari yurisdiksi pengadilan domestik.

Berdasarkan pengertian subyek hukum internasional di atas, maka yang termasuk sebagai subyek- subyek hukum internasional adalah sebagai berikut:

1. Negara

Negara merupakan subyek hukum internasional yang terpenting dibandingkan dengan subyek- subyek hukum internasional lainnya. Para ahli hukum mendefiniskan negara sebagai suatu lembaga atau suatu wadah dimana manusia mencapai tujuan- tujuannya dan dapat melaksanakan kegiatankegiatannya (Jawahir Thontowi dan 
Volume 1, Nomor 2 Oktober 2019

ISSN : 2656-9639 (Cetak)

ISSN : 2684-9046 (Online)

Pranoto Iskandar;2006). Pengertian negara secara yuridis disebutkan dalam pasal 1 Montevideo (Pan American) The Convention on Rights and Duties Of State Of 1933, yang berbunyi: "Negara sebagai subyek hukum dalam hukum internasional harus memiliki: (a). penduduk tetap, (b). wilayah tertentu, (c). pemerintahan, dan (d). kapasitas untuk berhubungan dengan negara lain". Dalam pasal 6 konvensi wina 1969 negara diartikan sebagai subyek hukum internasional yang memiliki kapasitas penuh untuk membuat atau mengadakan perjanjian internasional.

2. Organisasi internasional

Organisasi internasional adalah suatu organisasi yang dibentuk dengan perjanjian internasional oleh dua negara atau lebih yang berisi fungsi, tujuan, kewenangan, asas, struktur organisasi. Tidak semua organisasi internasional memiliki status sebagai subyek hukum internasional, hanya organisasi internasional yang memenuhi kerakteriskrik berikut yang diakui sebagai organisasi internasional, yaitu: (a). organisasi tersebut dibentuk dengan suatu perjanjian internasional oleh lebih dari dua negara, apapun namanya dan tunduk pada rezim hukum internasional, dan (b). organisasi tersebut memiliki sekretariat tetap. Dengan terpenuhi kedua karakteristik tersebut akan lenih mudah organisasi itu untuk memperoleh international personality. Karena dengan international personality yang dimiliki oleh suatu organisasi internasional akan memiliki kecakapan hukum internasional (international legal capacity). International legal capacity yang dimiliki oleh organisasi internasional antara lain:

a. Dapat membuat perjanjian internasional dengan sesama organisasi internasional, negara atau subjek hukum internasional lainnya

b. Dapat memiliki property atas nama namanya sendiri

c. Dapat melakukan perbuatanperbuatan hukum untuk dan atas nama anggota- anggotanya

d. Dapat menuntut dan dituntut dipengadilan internasional (Sefriani).

\section{Individu}

Pada awalnya individu hanya diakui sebagai subyek hukum nasional, dan kemudian indivisu diakui sebagai subyek hukum internasional jika telah mendapatkan persetujuan atau izin dari negara, karena subyek hukum internasional adalah negara. Namun sekarang, individu dalam batas-batas tertentu dapat bertindak atas nama dan untuk dirinya sendiri dalam wilayah hukum internasional, serta dapat dibebani kewajiban-kewajiban internasional dan dimintakan pertanggungjawaban atas perbuatannya yang bertentangan dengan hukum internasional (Jawahir Thontowi dan Pranoto Iskandar). Orang perorangan (individu) diakui sebagai subyek hukum internasional, Karena kepadanya diberikan hak untuk menuntut di pengadilan internasional berdasarkan konvensi atau perjanjian. Salah satu contoh yang mengakui status individu sebagai subyek hukum internasional adalah perjanjian perdamaian Versailles tahun 1919, perjanjian antara Jerman dan Polandia 1922 tentang Silesia Atas, dan keputusan tetap Mahkamah Internasional dalam perkara yang menyangkut pegawai kereta api Danzig.

4. Tahta Suci (Vatikan)

Tahta suci yang terletak di Kota Vatikan diakui sebagai subyek hukum internasional tidak terlepas dari faktor historis. Semenjak penaklukannya oleh 
Volume 1, Nomor 2 Oktober 2019

ISSN : 2656-9639 (Cetak)

ISSN : 2684-9046 (Online)

tentara Italia, kedaulatan Tahta suci sebagai negara berakhir. Namun kemudian Tahta Suci dengan Italia menandatangani the Leteran Treaty pada tahun 1929 yang di dalamnya memberikan pengakuan atas kota Vatikan dan kedaulatannya yang sesuai dengan sifatnya dan mendukungnya menjalankan misinya di dunia. Kewenangan tahta suci sebagai subyek hukum internasional hanya terbatas dalam masalah kemanusiaan dan perdamaian umat, sehingga tampak sebagai kekuatan moral belaka. Namun pengaruh dan wibawa Paus sebagai kepala tahta suci atau pemimpin gereja katolik diakui oleh seleuruh penjuru dunia (Jawahir Thontowi dan Pranoto Iskandar).

5. Organiasasi Pembebasan dan Pemberontak (Belligerent)

Bangsa yang sedang memperjuangkan haknya adalah suatu bangsa yang berjuang memperoleh kemerdekaan melawan negara asing yang menjajahnya. Meskipun banyak yang menamakan sebagai organisasi pembebasan, tetapi tidak semuanya mendapatkan pengakuan sebagai subyek hukum internasional. Hal ini dikarenakan tidak ada ktiteria objektif untuk menentukan apakah suatu kelompok sudah berhak menyandang status sebagai organisasi pembebasan atau bangsa yang memperjuangkan haknya atau belum. Kejadian pemberontakan dari kaum separatis merupakan urusan intern negara yang bersangkutan. Hukum internasioanl sendiri melarang negara lain untuk tidak melakukan intervensi tanpa adanya persetujuan negera tersebut. Namun demikian apabila pemberontakan dalam suatu negara telah mengambil porsi sedemikian rupa, sehingga negeranegara lain tidak mungkin lagi menutup mata terhadap kejadian tersebut, maka terpaksa negara-negara lain dengan sesuatu cara menunjukkan perhatian mereka dengan pengakuan (renognition of insurgency). Bila kaum pemberontak telah bertambah kuat kedudukannya sehingga mampu menguasai secara de facto suatu wilayah yang cukup luas dan telah mempunyai pemerintahan sendiri, maka akan pengakuan terhadap belligerent. Pada umumnya ada empat unsur yang harus dipenuhi oleh kaum pemberontak untuk mendapatkan pengakuan sebagai billegerent, yaitu:

a. Terorganisir secara rapi dan teratur diwilayah kepemimpinan yang jelas.

b. Harus menggunakan tanda pengenal yang jelas yang menunjukkan identitasnya

c. Harus sudah menguasai secara efektif sebagian wilayah sehingga wilayah tersebut benar- benar telah dibawah kekuasaanya

d. Harus mendapat dukungan dari rakyat diwilayah yang didudukinya.

6. International Committee on the Red Cross (ICRC)

ICRC atau Palang Merah Internasional merupakan organisasi non pemerintah yang bergerak di bidang kemanusiaan, beranggotakan palang merah nasional beberapa negara dan berkedudukan di Swiss. ICRC diakui sebagai subjek hukum internasional secara khusus karena secara historis, ICRC telah memberikan peran besar dalam memberikan pertolongan korban perang khususnya Perang Dunia I dan Perang Dunia II serta ICRC telah memberikan kontribusi besar dalam pembentukan konvensi-konvensi Jenewa 1949.

7. Organisasi Pembebasan (National Liberation Organization)

Organisasi Pembebasan atau bangsa yang memperjuangkan haknya adalah suatu bangsa yang berjuang memperoleh 
Volume 1, Nomor 2 Oktober 2019

ISSN : 2656-9639 (Cetak)

ISSN : 2684-9046 (Online)

kemerdekaan dari para penjajah. Tidak ada syarat objektif suatu bangsa dikatakan sebagai organisasi pembebasan karena pertimbangan politik masyarakat internasional terhadap kelompok tersebut termasuk dalam kategori organisasi pembebasan lebih diutamakan dibandingkan hukum internasional sebagai parameter kelompok tersebut. Secara historis, contoh organisasi pembebasan adalah South West Africa People (SWAPO) yang berjuang mendirikan Namibia melalui resolusi Majelis Umum PBB.

\section{Pembuatan Perjanjian Internasional}

Berkaitan dengan masalah pembuatan perjanjian internasional telah diatur secara yuridis dalam aturan perjanjian internasional yaitu dalam konevnsi Wina 1969 dan dalam Undang-Undang Nomor 24 Tahun 2000. Di dalam konvensi Wina 1969 sebagaimana yang telah disebutkan dalam Bab II Pasal 6 konvensi Wina 1969 menyebutkan bahwa: "setiap negara memiliki kapasitas untuk membuat perjanjian". Dalam pasal 6 Konvensi Wina 1969 tersebut dengan tegas menyebutkan bahwa yang dapat melakukan perjanjian (baik perjanjian internasional ataupun perjanjian lainnya) adalah negara, yaitu negara yang telah merdeka dan telah diakui oleh dunia internasional. Dapat disimpulkan bahwasanya negara dapat melakukan perjanjian internasional dengan siapa pun asalkan dengan salah satu subyek hukum internasional, serta para pihak yang terkait dalam perjanjian internasional tersebut harus melaksanakan hak dan kewajibannya sebagaimana yang telah disepakati dalam perjanjian internasional tersebut dengan iktikad baik tanpa adanya niat buruk atau merugikan salah satu pihak. Selanjutnya dalam Pasal 6 ayat (1) UU nomor 24 tahun 2000 juga menjelaskan secara tegas tahapan- tahapan pembuatan perjanjian internasional, yaitu sebagai berikut:

a. Tahap penjajakan

b. Tahap perundingan

c. Tahap perumusan naskah

d. Tahap penerimaan, dan

e. Tahap penandatangan.

Setelah semua tahapan tersebt terlaksana dengan baik oleh para pihak pembuat perjanjian internasional, selanjutnya naskah perjanjian internasional tersebut ditanda tangani oleh para pihak pembuat perjanjian. Di Indonesia, yang melakukan penandatanganan dalam suatu naskah perjanjian internasional harus mendapatkan surat kuasa dan surat kekercayaan, kecuali jika naskah perjanjian internasional tersebut ditanda tangani oleh presiden atau menteri. Hal ini sebagaimana diatur dalam pasal 7 ayat (1) - (5) UU nomor 24 tahun 2000.

\section{Analisis MoU Helsinki Ditinjau dari Perspektif Hukum Internasional Latar Belakang Munculnya MoU Helsinki}

Adanya ketidakpuasan masyarakat Aceh terhadap Pemerintah Indonesia memunculkan gerakan separatis yang diinisiasi oleh Gerakan Aceh Merdeka (GAM). GAM pada awal berdirinya merupakan perkumpulan kaum intelektual yang memperjuangkan Aceh untuk menjadi negara berdaulat terpisah dari NKRI sebagaimana Aceh di masa lalu yakni pada zaman Kesultanan Iskandar Muda. GAM lahir pada tanggal 4 Desember 1976 di sebuah camp Bukit Cokan, Pedalaman Kecamatan Tiro, Pidie (Moch. Nurhasim;2008). GAM terbentuk dan menuntut atas hak menentukan nasib sendiri (selfdetermination right) karena adanya kekecewaan-kekecewaan politik, 
Volume 1, Nomor 2 Oktober 2019

ISSN : 2656-9639 (Cetak)

ISSN : 2684-9046 (Online)

ekonomi dan sosial rakyat Aceh terhadap Pemerintah Pusat RI.

Kekecewaankekecewaan tersebut secara historis berkaitan dengan perkembangan GAM. Menurut Isa Sulaiman, perkembangan GAM dibagi menjadi tiga periode, yaitu (Moch. Nurhasim):

a. GAM Generasi Pertama (1976-1982)

$$
\text { Merupakan kelahiran dan }
$$

konsolidasi GAM, hasil dari propaganda. Awal lahirnya GAM diinisiasi oleh Hasan di Tiro, seorang tokoh GAM yang pernah menjadi Duta Besar Republik Indonesia di Amerika Serikat dan PBB pada Pemerintah Ali Sostroamidjodjo. Hasan di Tiro berpendapat bahwa Aceh mengalami ketidakadilan dari Pemerintah Indonesia hingga menuduh Pemerintah Indonesia telah melakukan kejahatan genosida terhadap rakyat Aceh (Mohammad Hasan Anshori, 2012). Tiro mengemukakan bahwa ketidakadilan tersebut diantaranya berupa: Pertama, kolonialisasi orang Jawa pada setiap pekerjaan di Aceh atau bentuk ketatanegaraan Indonesia yang unitaris sehingga menimbulkan dominasi suku. Kedua, eksplorasi hasil minyak di Aceh Utara yang hasilnya diserahkan kepada Pemerintah Pusat dan kurang mensejahterakan masyarakat Aceh. Penemuan di sekitar pemukiman masyarakat Arun pada tahun 1960an yang bersamaan dengan krisis energi dunia. Kawasan tersebut dibangun pusatpusat investasi besar berupa PT. Arun (1974) dan dalam waktu 4 tahun, di Blang Lancang berdiri pabrik pencairan minyak terbesar di dunia, sehinga wilayah industri ini dinamakan ZILS (Zona Industri Lhokseumawe). Ketidakadilan atas pengelolaan hasil sumber daya alam ini pun mempengaruhi masyarakat Aceh untuk mengajukan tuntutan atas self- determination right. Ketiga, syariat islam yang ingin dijadikan filsafat atau ideologi negara. Disisi lain ada yang berpendapat bahwa Hasan di Tiro kecewa atas penolakan Pemerintah Indonesia terhadap tawaran Hasan di Tiro yang menawarkan penguasa kontraktor dari Amerika Serikat. Kemudian, Hasan di Tiro mengobarkan semangat patriotisme lokal untuk mencari dukungan. Hal tersebut terbukti dengan Hasan di Tiro mendapat dukungan dari tokoh DI/TII Daud Beureuh yang merasa persoalan pemberontakan DI/TII belum selesai pada era Soekarno. Beberapa faktor tersebut kemudian melatarbelakangi terbentuknya GAM.

b. GAM generasi kedua (1982-1989)

Terjadi aksi-aksi kekerasan dan kekacauan karena masuknya kelompok kriminal dalam tubuh GAM yang tujuannya sebagian besar adalah ekonomi bukan terkait dengan hak untuk menentukan nasib sendiri. Penyerangan tersebut ditujukan kepada perusahaanperusahaan dan ABRI. Misal perampasan senjata pada 26 September 1989 milik ABRI di Krueng Tuan yang dilakukan oleh Panglima GAM. Kelompok GAM pada generasi kedua tidak mendapatkan dukungan dari rakyat Aceh karena melakukan banyak kekejaman dan tidak sesuai dengan nilainilai kemanusiaan.

c. Generasi Ketiga (1989-2003)

Periode GAM mengembangkan sayap militernya dan hubungan diplomatik ke luar negeri. Kekuatan GAM pada generasi ketiga sangat besar, seperti GAM memiliki 5000-6000 prajurit. GAM mendapatkan dukungan dari rakyat Aceh terutama dari korban Daerah Operasi Militer (DOM). Selain hal tersebut, masyarakat Aceh mengalami beberapa kekecewaan. 
Volume 1, Nomor 2 Oktober 2019

ISSN : 2656-9639 (Cetak)

ISSN : 2684-9046 (Online)

Pertama, janji Bung Karno bahwa Aceh dibolehkan menjalankan syariat islam setelah Indonesia merdeka tidak dikabulkan. Kedua, pencabutan keistimewaan Aceh berdasarkan UU Nomor 5 Tahun 1974 yang mencabut keistimewaan Aceh pada UU Nomor 18 tahun 1965 tentang Pemerintahan Daerah yang menjelaskan bahwa Aceh memperoleh keistimewaan di bidang agama, adat-istiadat, dan pendidikan. Dapat disimpulkan bahwa adanya ketidakadilan dan kekecewaan yang dirasakan masyarakat Aceh terhadap kebijakan Pemerintah Pusat menimbulkan gerakan separtisme dinamakan GAM yang menuntut hak untuk menentukan nasib sendiri agar Aceh dapat berdiri sendiri menjadi sebuah negara berdaulat dan lebih mensejahterakan rakyat Aceh.

\section{Putaran Perundingan MoU Helsinki}

a. Perundingan Helsinki Putaran Pertama

Perundingan antara Pemerintah Indonesia dengan GAM putaran pertama berlangsung pada 27-29 Januari 2005 di Kompleks Koningstedt, Manor, Vantaa, Helsinki merupakan tahap penjajakan untuk membangun kepercayaan dan mengidentifikasi kemauan masingmasing pihak yang berunding. Agenda utama yang dilakukan pada perundingan ini adalah mendiskusikan masalah keamanan dan kemanusiaan di Aceh pasca-tsunami.

b. Perundingan Helsinki Putaran Kedua

Perundingan putaran keduan dilaksanakan pada tanggal 21-23 Februari 2005 di Kompleks Koningstedt, Manor, Vantaa, Helsinki berisi tentang penegasan Pemerintah Indonesia bahwa persoalan Aceh adalah persoalan dalam negeri sehingga Pemerintah Indonesia menentang campur tangan pihak asing dan penyelesaian Aceh diselesaikan dalam tataran otonomi khusus dan pengakhiran konflik secara permanen, bukan gencatan senjata. Pihak GAM tidak mengubah tuntutannya yakni tetap menolak otonomi khusus karena terminologi otonomi khusus sudah pernah diberlakukan dan tidak dapat menyelesaikan masalah Aceh. Kedua belah pihak masih bersikeras kepada tuntutan masing-masing hingga Martti melakukan lobi khusus dengan delegasi GAM. Adanya opsi konsep baru oleh GAM akibat ancaman apabila pihak GAM tidak mengubah posisi maka pihak Uni Eropa tidak bersedia membantu melindungi GAM karena posisi Martti yang penting dengan Uni Eropa.

c. Perundingan Helsinki Putaran Ketiga

Putaran ketiga ini dilaksanakan pada 12-16 April 2005 di Kompleks Koningstedt, Manor, Vantaa, Helsinki. Konsep self-government dari pihak GAM belum menjadi agenda pembicaraan dan delegasi RI belum menanggapi masalah tersebut. Pembahasan paling alot pada perundingan ini adalah persoalan partai lokal sebagai bentuk dari implementasi selfgovernment. Hal tersebut terjadi karena partai lokal bertentangan dengan UU Nomor 12 Tahun 2003 tentang Partai Politik dari sisi Pemerintah Indonesia, namun di sisi GAM partai lokal sangat berarti demi mewujudkan selfgovernment.

d. Perundingan Helsinki Putaran Keempat

Dilaksanakan pada tanggal 23-31 Mei 2005 di di Kompleks Koningstedt, Manor, Vantaa, Helsinki. Pembahasan pada perundingan ini adalah masih melanjutkan pembahasan ada putaran ketiga, yaitu partai lokal. Kedua belah 
Volume 1, Nomor 2 Oktober 2019

ISSN : 2656-9639 (Cetak)

ISSN : 2684-9046 (Online)

pihak menyetujui perlunya dokumentasi dan formulasi tertulis capaian yang telah dibicarakan kedua belah pihak sebagai dasar menyiapkan draft MoU.

e. Perundingan Helsinki Putaran Kelima

Dilaksanakan pada tanggal 12-17 Juli 2005 di Kompleks Koningstedt, Manor, Vantaa, Helsinki dengan agenda utama membahas masalah yang belum tuntas pada perundingan sebelumnya dan membahas rumusan draft $M o U$ yang telah disusun oleh CMI. Putaran ini terancam bubar karena delegasi RI masih mempersoalkan masalah partai lokal sebagai wujud dari self-government, namun pada akhirnya delegasi RI menerima kosnep partai lokal setelah Hamid menelpon Jusuf Kalla pada saat terjadi lobi dengan Nur Dzuli.

\section{Status Hukum MoU Antara GAM dengan Pemerintah RI}

Pada dasarnya status hukum MoU perdamaian antara GAM dengan pemerintah RI sangat tergantung pada status hukum GAM itu sendiri, apakah GAM dapat dikategorikan sebagai subyek hukum internasional sebagai salah satu kaum belligerent atau tidak. Apabila GAM termasuk kepada kaum belligerent dan termasuk ke dalam kategori subyek hukum internasional, maka secara otomatis status hukum MoU perdamaian GAM dengan pemerintah RI tergolong ke dalam perjanjian internasional. Dari tinjauan pusaka/ teori mengenai perjanjian internasional yang telah penulis bahas dalam bab sebelumnya. Penulis mengemukakan suatu pendapat, bahwasanya nota $\mathrm{MoU}$ perdamaian antara pihak GAM dengan pemerintah RI jika dianalisis berdasarkan perjanjian internasional, tidak termasuk ke dalam perjanjian internasional, dengan alasan sebagai berikut:

1. Subjek hukum dari MoU Helsinki adalah Pemerintah RI dan GAM. Pemerintah RI adalah wujud representasi dari negara. Negara merupakan subjek hukum internasional yang paling utama, terpenting dan memiliki kewenangan terbesar sebagai subjek hukum internasional yang dilekatkan dengan kecakapan-kecakapan hukum (Sefriani). Sedangkan GAM bukan merupakan organisasi pembebasan bangsa yang memperjuangkan haknya maupun belligerent. GAM hanya merupakan organasasi pemberontak nasional belum dianggap sebagai belligerent yang diakui oleh dunia internasional.GAM tidak dapat dianggap sebagai belligerent karena tidak memenuhi unsur-usnsur belligerent yang diterapkan oleh hukum internasional, yaitu:

Terorganisir secara rapi dan teratur di bawah kepemimpinan yang jelas atau under responsible command (Article 1 Paragraph 1 Additional Protocol II of 1977).

Dalam hal ini GAM telah memenuhi unsur ini, dimana struktur kepemimpinan GAM tersusun dengan rapi, jelas dan sistematis. Struktur ini ditetapkan pada tahun 1977 oleh Hasan di Tiro dengan menempatkan dirinya sebagai pemimpin di Aceh dengan sebutan wali negara (Syamsul Hadi, 2007). Struktur kepemimpinan GAM mulai dari pimpinan umum GAM yang dipimpin oleh Tengku Hasan Tiro sampai dengan kementerian- kementrian lainnya yang ada dalam struktur kepemimpinan GAM. Setelah 1979 kabinet tidak berfungsi lagi karena ada menteri yang terbunuh seperti Muchtar Hasbi, beberapa ditahan, dan sebagian lagi mencari perlindungan ke luar negeri 
Volume 1, Nomor 2 Oktober 2019

ISSN : 2656-9639 (Cetak)

ISSN : 2684-9046 (Online)

seperti Tiro, Zaini Abdullah, Malik Mahmud, dan Husaini Hasan (Kirsten E.Schulze, 2004). GAM dibagi menjadi dua struktur organisasi yaitu civilian government dan military structure.

a. Harus menggunakan tanda pengenal yang jelas

Unsur yang kedua ini juga dapat dipenuhi oleh GAM, hal ini dapat dilihat dari lambang atau logo GAM yang telah di buat dalam bentuk bendera resmi GAM. Pada tanggal 25 Maret 2013 DPRA resmi mengesahkan qanun nomor 2 tahun 2013 tentang bendera dan lambang Aceh dan telag diundangkan dalam lembaran Aceh tahun 2013 nomor 3 dan tambahan lembaran Aceh nomor 49.

b. Harus sudah menguasai secara efektif sebagian wilayah sehingga wilayah tersebut benar-benar telah berada di bawah kekuasaannya.

Unsur ketiga ini tidak dapat terpenuhi oleh GAM. Mengingat hanya beberapa wilayah saja yang dapat dikuasai oleh GAM, seperti wilayah Aceh Utara, Aceh Timur dan Sebagian kecil di Wilyah Aceh Besar serta Aceh Selatan. Sebelum nota MoU perdamaian antaran GAM dengan pemerintah RI ditanda tanagani di Helsinky pada 15 agustus 2005, dua tahun sebelum MoU terjadi tepatnya pada 2003 hanya 30 persen desa konflik di wilayah Aceh yang dapat dikuasai oleh GAM. Oleh karena itu dapat dikatakan bahwasanya tidak semua wilayah Aceh di kuasai oleh pihak GAM, jadi GAM tidak memenuhi unsur ini sebagai belligerent.

c. Harus mendapat dukungan dari rakyat diwilayah yang didudukinya

Unsur yang keempat ini hampir saling berkaitan dengan unsur belligerent sebelumnya. Jika dalam unsur sebelumnya pihak GAM hanya menguasai 30 persen desa konflik yang ada diwilayah Aceh, maka secara otomatis dapat dikatakann tidak semua masyarakat Aceh mendukung apa yang dilakukan pihak GAM. Oleh karena itu GAM juga tidak memenuhi unsure keempat ini sebagai belligerent. Dari keempat unsur belligenrent tersebut di atas, maka dapat disimpulkan bahwa GAM tidak termasuk ke dalam kelompok belligerent. Oleh karena itu nota MoU antara GAM dengan pemerintah RI tidak dapat dikategorikan sebagai perjanjian internasional. Karena dengan jelas salah satu pelaku (GAM) atau subyek dalam nota MoU perjanjian perdamaian tersebut bukan merupakan subyek hukum internasional yang diakui oleh dunia internasional.

2. Perjanjian perdamaian antara GAM dengan pemerintah RI tidak dapat dikatakan sebagai perjanjian internasional karena adanya pihak ketiga atau pihak asing dalam pelaksanaan Nota MoU antara GAM dengan pemerintah RI, hanya merupakan sebagai pihak fasilitator terhadap pelaksanaan $\mathrm{MoU}$ tersebut. Dikatakan sebagai pihak fasilitator karena pihak asing yaitu mantan presiden Finlandia Martti Ahtissaari yang juga mejabat sebagai presiden Crisis Management Initiative (CMI) mengajak kedua belah pihak yang berseteru antara GAM dengan pemerintah RI untuk melakukan perundingan perdamaian secara kekeluargaan dengan harapan untuk mencapai kata kesepakatan dan mengakhiri peperangan local yang terjadi antara kedua belah pihak GAM dengan pemerintah RI. Dengan segala perundingan dan persyaratan yang diajukan oleh para pihak antara GAM dengan pemeritah RI, maka pada tanggal 15 Agustus 2005 yang bertempat di Helsinky, Finlandia tercapainya perdamaian antara GAM dengan 
Volume 1, Nomor 2 Oktober 2019

ISSN : 2656-9639 (Cetak)

ISSN : 2684-9046 (Online)

pemerintah RI, dimana penandatanganan nota MoU perdamaian antara GAM dengan pemerintah RI (yang disebut juga sabagai MoU Helsinky) disaksikan oleh Martti Ahtissaari.

3. Adanya pihak asing dalam pelaksanaan MoU GAM dengan pemerintahan RI tersebut hanya merupakan sebatas iktikad baik negara lain untuk membantu menyelesaikan konflik/ sengketa yang terjadi antara GAM dengan pemerintah RI. Masuknya pihak negara asing dalam persengketaan antara GAM dengan pemerintah RI bukan untuk membela atau memihak kepada salah satu pihak, melainkan karena melihat persengketaan yang terjadi antara GAM dengan pemerintah RI yang sudah cukup lama yang belum terselsaikan serta ditakuti akan terjadinya persengketaan local yang berkepanjangan. Oleh karena demikian, masuknya pihak asing, mantan presiden Finlandia Martti Ahtissaari yang juga mejabat sebagai presiden Crisis Management Initiative (CMI) dalam persengketaan ini bertujuan untuk melakukan jasa baik atau good offices. Keterlibatan pihak ketiga dalam good offices tidak lebih dari untuk mengupayakan pertemuaan para pihak yang bersengketa (dalam kasus ini pihak GAM dengan pemerintah RI) untuk berunding, dan pihak yang melakukan good offices tersebut tidak terlibat di dalam perundingan itu sendiri (Sefriani). Dalam kasus ini mantan presiden Finlandia telah berhasil melakukan jasa baik atau good offices terhadap pemerintah Republik Indonesia dengan Gerakan Aceh Merdeka (GAM) yang telah menandatangani nota $\mathrm{MoU}$ perdamaian untuk mengakhiri perselisihan yang terjadi selama ini seacara damai pada 15 Agustus 2005 di Helsinky, Finlandia.
4. Secara yuridis jika dianalisis berdasarkan pasal 4 ayat (1) UU nomor 24 tahun 2000 tentang perjanjian internasional. MoU antara GAM dengan pemerintah RI juga tidak dapat dikategorikan sebagai perjanjan internasional, hal ini dikarenakan yang berhak mengadakan perjanjian internasional sebagaimana yang diatur secara yuridis dalam pasal 4 ayat (1) tersebut adalah suatu negara dengan subyek hukum internasional lainnya. Sedangkan dalam kasus MoU antara GAM dengan pemrintahan RI ini, hanya negara republic Indonesia yang dapat dikatakan sebagai subyek hukum internasional yang sah dan diakui oleh dunia internasional, sementara GAM tidak digolongkan kedalam subyek hukum internasional (dengan alasan sebagaimana yang telah penulis uraikan dalam pemabahasan di atas).

\section{MoU Helsinki Tidak Tunduk Terhadap Hukum Internasional (Governed by International Law)}

Maksud "governed by international law" yang didalamnya melekat elemen "intention to create obligation under international law" menurut Vienna Convention on the Law of Treaties adalah untuk membedakan antara perjanjian internasional yang diatur dengan hukum internasional (publik) dan perjanjian internasional yang meskipun para pihak adalah antarnegara tetapi diatur dengan hukum nasional salah satu pihak atau hukum negara lain yang disepakati oleh para pihak. MoU Helsinki tunduk pada hukum nasional Indonesia, "the government of the Acehnese people can be manifested through a fair and democratic process within the unitary state and constitution of the Republic of Indonesia (MoU between the GoI and 
Volume 1, Nomor 2 Oktober 2019

ISSN : 2656-9639 (Cetak)

ISSN : 2684-9046 (Online)

the Free Aceh Movement). Di sisi lain, dalam Pasal 1 (4) (2) dan Pasal 2 (1) $M o U$ Helsinki mencantumkan sumber hukum internasional yaitu prinsipprinsip universal hak asasi manusia sebagaimana tercantum dalam Kovenan Internasional Perserikatan Bangsabangsa mengenai Hak-hak Sipil dan Politik dan mengenai Hak-hak Ekonomi, Sosial dan Budaya. Namun, hal tersebut bukan berarti bahwa $M o U$ Helsinki tunduk pada hukum internasional.

Sifat dari pihak yang terikat (nature of the contracting parties) dibutuhkan dalam membuat perjanjian antar negara agar tunduk pada hukum internasional (Draft Articles on the Law of Treaties with commentaries 1966). MoU Helsinki harus membuktikan terpenuhi elemen "nature of contracting parties" tersebut. GAM sebagai salah satu pihak dari $M o U$ Helsinki memiliki sifat bukan merupakan subjek hukum internasional sehingga tidak dapat dikatakan sebagai pernjanjian yang tunduk pada hukum internasional. Selain itu menurut Parthiana, "governed by international law" harus dibuktikan sejak perundingan, pembuatan naskah perjanjian, pemberlakuan, pelaksanaan, hingga penyelesaian sengketa, perjanjian internasional ini harus tunduk kepada hukum internasional, dengan penjelasan sebagai berikut (I Wayan Parthiana) :

\section{a. Perundingan}

Saat perundingan $M o U$ Helsinki, para pihak melakukan pendekatan informal terlebih dahulu yaitu melalui upaya yang dilakukan Juha Christensen sebagai mediator dengan GAM yang diwakili oleh Malik Mahmud dan Bachtiar Abdullah pada 30 Januari di rumah Juha hingga menuju pendekatan formal yang difasilitasi oleh suatu organisasi internasional sebagai pihak ketiga, CMI di Helsinki, Finlandia.
Disebut (Moch. Nurhasim) sebagai pertemuan informal karena dua alasan yaitu pertama, Pemerintah Indonesia belum mengakui secara resmi keberadaan GAM sebagai sebuah negara (state), sifat informal tersebut merupakan strategi Pemerintah Indonesia untuk menghindari adanya negara dalam negara dan menghindari dampak internasionalisasi terhadap kasus separatisme Aceh. Kedua, berkaitan dengan strategi yang diterapkan oleh CMI bahwa perundingan tidak mengikat kedua belah pihak hingga para pihak menyepakati agenda bersama sehingga tidak adanya kecemasan tentang hal yang dibicarakan pada saat perundingan akan mengikat para pihak.

b. Pembuatan naskah perjanjian

Dilakukan dengan berbagai langkah formal sesuai Konvensi Wina 1969 seperti pertama, penunujukkan wakil dari pihak Pemerintah Indonesia diketuai oleh Hamid Awaluddin dan pihak GAM diketuai oleh Malik Mahmud. Kedua, penyerahan surat kuasa oleh masingmasing pihak. Pemerintah Indonesia memberikan kuasa penuhnya terhadap wakil-wakilnya melalui rapat terbatas Presiden RI dengan kabinetnya. Sedangkan GAM memberikan kekuasaan penuhnya kepada beberapa orang yang diambil dari luar Aceh dan luar negeri tidak ditentukan secara khusus oleh GAM, karena sedikitnya personil GAM yang berkemampuan cukup dalam berunding akibat kematian seperti Prof. Sofyan Sarifudin Tiba akibat tsunami, Omni Ahmad Basuki (komandan operasi GAM) yang dipenjara. Penyerahan kekuasaan oleh diberikan kepada Malik Mahmud, Zaini Abdullah (Menteri Luar Negeri GAM), Nur Dzuli (warga Malaysia yang merupakan anggota GAM), Bachtiar 
Volume 1, Nomor 2 Oktober 2019

ISSN : 2656-9639 (Cetak)

ISSN : 2684-9046 (Online)

Abdullah dan Nurdin Abdurrahman (warga Aceh di Sydney, Australia)

c. Pemberlakuan dan Pelaksanaan

Pemberlakuan perjanjian dapat dilihat berdasarkan tanggal penandatanganan $\mathrm{MoU}$ Helsinki yakni pada hari Senin, 15 Agustus 2005 sesuai dengan persetujuan kedua belah pihak. Pemberlakuan MoU Helsinki ditetapkan dengan ketentuan konsultasi dan persetujuan melalui legislatif Aceh terlebih dahulu. Pelaksanaan $\mathrm{MoU}$ Helsinki diterapkan melalui UndangUndang Pemerintah Aceh sebagaimana yang berbunyi sebagai berikut, " $A$ new Law on the Governing of Aceh will be promulgated and will enter into force as soon as possible and not later than 31 March 2006." “b) International agreements entered into by the Government of Indonesia which relate to matters of special interest to Aceh will be entered into in consultation with and with the consent of the legislature of Aceh..."

\section{d. Penyelesaian Sengketa}

Apabila terjadi sengketa berkaitan dengan pelaksanaan $M o U$ Helsinki maka akan diselesaikan dengan beberapa cara yaitu pertama, akan diselesaikan oleh Kepala Misi Monitoring melalui musyawarah para pihak. Kedua, apabila tidak dapat diselesaikan maka sengketa akan dibahas antara Kepala Misi Monitoring dengan wakil senior dari para pihak. Ketiga, apabila sengketa tidak dapat juga diselesaikan maka Kepala Misi Monitoring akan melaporkan kepada Menteri Koordinator Politik Hukum dan Keamanan Republik Indonesia, pimpinan politik GAM dan Ketua Dewan Direktur CMI serta memberitahu Komite Politik dan Keamanan Uni Eropa, kemudian setelah berkonsultasi maka Ketua Dewan Direktur CMI akan mengambil keputusan yang mengikat para pihak. Ketentuan penyelesaian sengketa pada $M o U$ Helsinki telah sesuai dengan ketentuan hukum internasional bahwa upaya damai harus diutamakan kemudian tindakan lain sesuai dengan hukum internasional dapat dilakukan. Melalui analisis terhadap pendapat Wayan Parthiana atas "governed by international law," MoU Helsinki kurang tepat jika dikatakan tunduk terhadap hukum internasional karena terdapat kekurangan pada saat pembuatan naskah perjanjian yaitu tidak adanya penunjukkan secara khusus GAM terhadap wakilnya di meja perundingan, berbeda halnya dengan Indonesia. Berdasarkan penjelasan diatas terkait dengan unsur perjanjian internasional menurut Konvensi Wina 1969, Konvensi Wina 1986 dan analisis terhadap pendapat ahli hukum perjanjian internasional (Parthiana) mencerminkan bahwa $M o U$ Helsinki tidak tunduk pada hukum internasional (governed by international law) karena salah satu pihak terkait (GAM) bukan merupakan subjek hukum internasional.

\section{Simpulan}

pada dasarnya status hukum MoU perdamaian antara pihak Gerakan Aceh Merdeka (GAM) dengan pihak pemerintah Republik Indonesia (RI) sangat tergantung terhadap status hukum GAM itu sendiri. Apakah ia termasuk kedalam kaum belligerent sehinggat dapat dikategorika ke dalam subyek hukum internasional atau tidak. Karena apabila GAM dianggap sebagai satu kaum belligerent, maka secara langsung nota MoU perdamaian tersebut dapat digolongkan ke dalam perjanjian perdamaian internasional, dan juga sebaliknya. Dalam hal ini penulis beropini bahwa GAM tidak termasuk ke 
Volume 1, Nomor 2 Oktober 2019

ISSN : 2656-9639 (Cetak)

ISSN : 2684-9046 (Online)

dalam kaum belligerent, ini disebabkan karena GAM tidak memenuhi unsurunsur untuk dapat dikatakan sebagai belligerent. Bahwasanya status hukum MoU perdamaian antara pihak Gerakan Aceh Merdeka (GAM) dengan pihak pemerintah Republik Indonesia (RI) tidak termasuk kepada perjanjian internasional. Hal ini dikarenakan salah satu pihak yang melakukan dan menandatangani nota MoU tersebut yaitu GAM tidak termasuk dalam kategori subyek hukum inernasional. GAM hanya merupakan kaum pemberontak local (nasional) yang ada di Aceh (Indonesia) yang tidak dianggap oleh kaum belligerent oleh dunia internasional. Meskipun adanya pihak asing dalam nota MoU GAM dengan pemerintahan RI, tetap saja MoU tersebut tidak dapat dikategorikan sebagai perjanjian internasional, karena pihak asing dalam nota MoU tersebut hanya sebagai fasilitator dalam pelaksanaan serta penandatanganan nota kesepahaman.

\section{Saran}

Mengenai status hukum MoU antara GAM dengan pemerintah RI itu sendiri bermacam-macam, setiap orang berhak menyimpulkan dan berpendapat sesuai dengan opini masing- masing. Dalam hal ini penulis menyarankan agar dalam berpendapat harus sesuai dengan referensi- referensi yang jelas. Penulis juga member kritikan kepada penulis terhadap tulisan ini. Dan saran penulis kepada para pemerintah RI agar dapat menentukan apakah MoU tersebut dapat digolongkan kepada perjanjian internasional atau tidak.

\section{Daftar Pustaka Buku}

Jawahir Thontowi dan Pranoto Iskandar, Hukum Internasional Kontemporer, Bandung: PT. Refika Aditama, 2006.

Moch. Nurhasim, Konflik dan Integrasi Politik Gerakan Aceh Merdeka; Kajian tentang Konsensus Normatif antara RI-GAM dalam Perundingan Helsinki, Yogyakarta: Pustaka Pelajar, 2008

Sefriani, Hukum Internasional Suatu Pengantar, Jakarta: Rajawali Press, 2010.

Sugeng Instanto, Hukum Internasional, Yogyakarta: Universitas Atma Jaya, 2010.

T. May Rudy, Hukum Internasional 2, Jakarta: PT. Refika Aditama, 2002.

\section{Jurnal}

Kirsten E.Schulze, 2004, The Free Aceh Movement (GAM): Anatomy of a Separatist Organization, Policy Studies 2, East-West Center, Washington DC, ISBN 1932728023

Mohammad Hasan Anshori, 2012, From insurgency to bureaucracy: Free Aceh Movement, Aceh Party and the New Face of Conflict, Stability: International Journal of Security\& Development, ISSN: 2165-2627 Syamsul Hadi, 2007, Disintegrasi Pasca Orde Baru: Negara, Konflik Lokal, dan Dinamika Internasional, e-book, Yayasan Obor Indonesia, ISBN 9794616249.

\section{Undang- Undang}

Draft Articles on the Law of Treaties with commentaries 1966

Konvensi Wina 1969

Protokol II Tambahan 1977 
Volume 1, Nomor 2 Oktober 2019

ISSN : 2656-9639 (Cetak)

ISSN : 2684-9046 (Online)

\section{Internet}

Official Waru. 2012. Sejarah Lahirnya

GAM. Diakses dari

officialwaru.wordpress.com, pada tanggal 15 Juni 2019, pukul 14.53 WITA.

Terjemahan Nota Kesepahaman Antara Pemerintah Republik Indonesia dengan Gerakan Aceh Merdeka. 